\title{
Adaptability of Different Sunflower Hybrids to the Conditions of Insufficient Moisturening
}

\author{
YEREMENKO OKSANA \\ Faculty of Agrotechnologies and Ecology \\ Dmytro Motornyi Tavria State Agrotechnological University \\ 18, B. Khmelnytsky Ave., 72312, Melitopol \\ UKRAINE \\ FEDORCHUK MYKHAILO \\ Faculty of Agricultural Technologies \\ Mykolayiv National Agrarian University \\ 9, Georgiya Gongadze str., 54020, Mykolayiv \\ UKRAINE \\ DROBITKO ANTONINA \\ Faculty of Agricultural Technologies \\ Mykolayiv National Agrarian University \\ 9, Georgiya Gongadze str., 54020, Mykolayiv \\ UKRAINE \\ SHARATA NATALIYA \\ Faculty of Agricultural Technologies \\ Mykolayiv National Agrarian University \\ 9, Georgiya Gongadze str., 54020, Mykolayiv \\ UKRAINE \\ FEDORCHUK VALENTINA \\ Faculty of Agricultural Technologies \\ Mykolayiv National Agrarian University \\ 9, Georgiya Gongadze str., 54020, Mykolayiv \\ UKRAINE
}

Abstract: Expansion of variety and sustainable production of quality oilseed crops both in the world on the whole and in Ukraine in particular, is actual. The main factors of this are: the urgent need for raw materials, changes in weather and climatic conditions, changes in the structure of phytocenoses, development and spread of specific diseases and pests, and adaptive ability of species and varieties, etc. This problem is especially crucial when cultivating crops under stressful conditions of the Southern Steppe of Ukraine. In the cultivation of sunflower varieties and hybrids of modern plant breeding, we observe a pronounced reaction to changes in agricultural meteorological conditions of their cultivation. Our research was carried out for three years (2017-2019) in the Southern Steppe region of Ukraine, which has low rainfall. The methods of the analysis were field and mathematicalstatistical methods. We evaluated the levels of environmental plasticity in 23 sunflower hybrids. We used the Eberhard and Russel method (the plasticity and stability analysis) to fully evaluate new hybrids with regard to their adaptability to growing conditions and investigate the appropriate rate of response of genotypes to the growing technology. We have found that under the conditions of the Dry Steppe zone of Ukraine sunflower embodies its genetic potential by $45 \%$. Based on the experimental data, we conducted the regression analysis resulting in a linear regression model that indicates the dependence of sunflower yield on agricultural meteorological indicators. The hydrothermal coefficient in 2017 was 0.75 . Despite this, the sunflower plants formed the highest yield that year due to the 
sufficient minimum relative humidity of the air during flowering (BBCH 61-65) was $54.7 \%$. Creating genotype shave an average value of plasticity of the yield (ranging from 0.83 to 1.19), namely: EU Arcadia SU, EU Genesis, NS-X-496, EU Generalis SL, EU Loris KLP, SI Bacardi KLP, SI Arizona. Hybrids of different intensity levels, that are genetically and biologically diverse, can be cultivated efficiently in different agricultural ecological growing zones.

Key-Words: adaptability; hybrids; plasticity coefficient; stability coefficient; sunflower.

Received: September 16, 2019. Revised: May 9, 2020. Accepted: May 19, 2020. Published: May 19, 2020.

\section{Introduction}

Sunflower (Helianthus annus L.) of the Asteraceae family, is an oilseed crop with important agronomic characteristics, showing greater resistance to drought, cold and heat compared to most of the species. It shows ample adaptability to different edaphic and climatic conditions and its yield is little influenced by latitude, altitude or photoperiod [1].

Optimization of the production process of sunflower agrophytocenoses for establishing patterns of the plant growth and development, the adaptive potential of the species, the variety and development of antis tress techniques in adaptive technologies for their cultivation on this basis, is extremely relevant. Nowadays, in the theoretical and practical components of world technologies of crops cultivation of field more and more attention is paid to the adaptive capacity of plants to biotic and a biotic stress factors [2].

Plant breeders create highly productive sunflower varieties and hybrids, resistant to unfavourable biotic and a biotic environmental factors [3]. In recent years, significant fluctuations of hydrothermal indices between years have occurred even in the same soil and climatic locations, providing a significant effect on the exhibition of individual characteristics and properties of agricultural crops and, as a result, of their macrocharacteristics, including yield $[4,5]$.

The plant breeders face the task of increasing the adaptive capacity of plants to adverse conditions of cultivation when they creating new varieties and hybrids of sunflower.Highly adapted varieties and hybrids are the key to a stable yield in varying agricultural meteorological conditions and different eco-geographical zones [6]. The assessment of adaptive and stability capacities of seed material is a prerequisite for the selection of highly adaptive forms $[7,8]$.

Today, the growth rate of the number of foreign selection hybrids exceeds the growth rate of the number of domestic sunflower varieties and hybrids by almost $10 \%$ [9]. In 2013449 varieties and hybrids of sunflower, both foreign and domestic selection, were registered on the territory of Ukraine; in 2015, this figure was already 642, and in 2019 it was 850 . Based on such a diversity of varieties and hybrids, the question to agrarians appears: "How to choose the most adapted variety or hybrid for certain climatic conditions of the region?". Global climate changes and the weather in the regions cause changes in the environment - increasing temperatures, uneven and missing precipitation, droughts, etc., in connection with which a significant impact of various negative factors on the yield and crop quality is predicted [10].

One of the most important requirements of production, that appears for modern hybrids and varieties of sunflower is the ability to consistently show signs of productivity under different growing conditions, as well as to respond positively to their improvement, is to be plastic [11, 12, 13]. A phenotypically plastic genotype shows a broad range of phenotypes [14]. Homeostasis, or canalization, refers to the opposite response, when the individual is insensitive to changes in the environment [15]. Thus, environmental canalization and phenotypic plasticity can be viewed as the two possible extremes of the response to changes in the environment [16].

At the present stage of the science development, methods of mathematical modelling (especially such as the cluster analysis, the Eberhard and Russel method for studying stability and plasticity, etc.) are playing an increasingly important role in the 
adequate evaluation of sunflower varieties and hybrids [17].

Ecological plasticity of a genotype is defined by S.A. Eberhart, et al. [18] and Q.C.C. Tai [19] as its ability to demonstrate an adequate response to changes in the production conditions, while V.N. Mamontova [20], V.Z. Pakudin, et al. [21] understand this as a genotype ability to form a stable high yield quality under different soil and climatic conditions, and respond to the improvement of cultivation technology.

There are many methods for determining the ecological plasticity and stability (adaptation of a variety or hybrid to certain climatic conditions). They differ both in the degree of complexity of calculations and in the approaches: regression, cluster, variance approaches and others [22, 23, 24, 25]. Most of these methods are used by plant breeders in their research and they are more time consuming.

Hybrids differently develop their productivity potential under different cultivating conditions. In order to maximize the productivity of sunflower hybrids in different growing regions, it is important to know the inadaptability potential, which is estimated by environmental plasticity and stability. These signs characterize the features of the adaptation of a hybrid to environmental conditions, give an idea of the advent ages and disadvantages of different hybrids, their behavior in different cultivating conditions [26].
The Southern Steppe zone of Ukraine has a high enough yield potential of oilseed crops, which can be realized only under the conditions of full and combined action of all factors. Presently, and in the future, the main limiting factor for cultivating of oilseed crops is and will be the moisture: both in the soil and air.

\section{Materials and Methods}

The research was carried out in the low humidity zone in the demonstration plots of "Energy 2000" Ltd (Melitopol district, Zaporizhzhia region, Ukraine) for three years (2017 - 2019).

The type of soil in study plots was represented by black soil containing $2.91 \%$ of humus, $81.5 \mathrm{mg} / \mathrm{kg}$ of light hydrolyzed nitrogen, $138.4 \mathrm{mg} / \mathrm{kg}$ of labile phosphorus, and $165.8 \mathrm{mg} / \mathrm{kg}$ of exchange potassium as the weighted average. The soil solution $\mathrm{pH}$ was approximately neutral [27]. During soil preparation a soil sample taken from the experimental plot was air-dried. Then all the roots were carefully removed and the soil was screened through sieves with openings of 1 $\mathrm{mm}$ and $0.25 \mathrm{~mm}$ [28].

According to the Turin's method which is based on the oxidation of soil organic matter by a solution of potassium dichromate $\left(\mathrm{K}_{2} \mathrm{Cr}_{2} \mathrm{O}_{7}\right)$ prior to the formation of carbon dioxide the content of humus in the soil was determined [29]. The reaction is represented by the following equation:

$$
3 \mathrm{C}+\mathrm{K}_{2} \mathrm{Cr}_{2} \mathrm{O}_{7}+\mathrm{H}_{2} \mathrm{SO}_{4}=2 \mathrm{~K}_{2} \mathrm{SO}_{4}+2 \mathrm{Cr}_{2}\left(\mathrm{SO}_{4}\right)_{3}+8 \mathrm{H}_{2} \mathrm{O}+3 \mathrm{CO}_{2}
$$

As a result of the Mohr's salt titration (from dark brown to emerald colour), we obtain values of organic carbon content in the soil which are converted into percentage of humus in the soil with mathematical calculations.

Determination of hydrolyzed nitrogen by Cornfield [30]. The method is based on the hydrolysis of nitrogen from the soil using alkali $(\mathrm{NaOH})$. Nitrogen released from the soil in the form of $\mathrm{NH}_{3}$ compounds is bound by boric acid. Subsequently we titrate the sample with a sulfuric acid solution $\left(1 / 2 \mathrm{H}_{2} \mathrm{SO}_{4}\right)$ until the indicator colour changes from green to pink.

Determination of labile forms of phosphorus and potassium in the soil is carried out by the Chirikov's method with 0.5 normal acetic acid, phosphorus and potassium are moved from the soil to the soil solution at the $1: 25$ ratio [31]. We determine phosphorus in the form of blue molybdenum with the photoelectric colorimeter and potassium with the flame photometer. 
The moisture content of the soil during the years of research varied in the amount of rainfall and the uniformity of its distribution in the soil horizon. During the 2018 growing season, the lowest rainfall occurred $(142 \mathrm{~mm}$; HTC $=0.50)$ and the highest one was in 2017 $(212 \mathrm{~mm}$; HTC $=0.75)$. The year 2019 was abnormal due to the uneven rainfall $(\mathrm{HTC}=$
0.67) and high temperatures. During the flowering period the minimum relative humidity was $42.6 \%$ (Table 1 ). In terms of relative humidity in the flowering period (54.7\%) and rainfall uniformity, 2017 was more optimal. There is no significant difference between the years in terms of active temperatures and units of thermal energy.

Table 1: Agricultural meteorological conditions of the growing season of sunflower (2017-2019)

\begin{tabular}{|c|c|c|c|}
\hline Indexes & 2017 & 2018 & 2019 \\
\hline Rainfall during the growing season, mm & 212 & 142 & 202 \\
\hline The sum of active (above $+10^{\circ} \mathrm{C}$ ) temperatures, ${ }^{\circ} \mathrm{C}$ & 2842 & 2829 & 3008 \\
\hline $\mathrm{CHU}^{*}$ & 3438 & 3471 & 3465 \\
\hline Hydrothermal coefficient & 0.75 & 0.50 & 0.67 \\
\hline Minimum relative air humidity during flowering, $\%$ & 54.7 & 39.2 & 42.6 \\
\hline
\end{tabular}

*Crop Heat Units - CHU [32].

The hydrothermal coefficient (HTC) indicator of moisture content of the territory [33]. Using the formula:

$$
H T C=\frac{\sum K}{\sum T} \cdot 10
$$

$\sum \kappa-$ rainfalls during the growing season (above $+10^{\circ} \mathrm{C}$ ), $\mathrm{mm}$;

$\sum \mathrm{T}-$ the sumo factive (above $+10^{\circ} \mathrm{C}$ ) temperatures, ${ }^{\circ} \mathrm{C}$.

The methods used in the experiment were common to the Steppe zone of Ukraine. The total size of an elemental area was $150 \mathrm{~m}^{2}$, count area $-58 \mathrm{~m}^{2}$.

Sowing was carried out at the beginning of the third decade of April. The sowing norm was $55,000 \mathrm{pcs} / \mathrm{ha}$ and the row spacing was 70 $\mathrm{cm}$. Winter wheat was used as a fore crop. The following specimens were used for seed disinfection: "Maxim XL" (active substance :mefenoxam, $10 \mathrm{~g} / 1$ and fludioxonil, $25 \mathrm{~g} / \mathrm{l}$ ) and "Cruiser" (active substance:thiamethoxam, 350 g/l) [34]. Experimental studies were carried out according to the method of field experiment [35].

The Eberhard and Russel method [18] was used to analyze features of ecological manifestation of plasticity and stability as the main commercially valuable traits of sunflower. Statistical results including the variance analysis and the cluster analysis were used to process all the results obtained during our research.

\section{Results and Discussion}

In general, the entire zone of the Southern Steppe of Ukraine is characterized by the high soil fertility, the excessive heat and sunlight, the long frost-free period and, as a consequence, favourable conditions for cultivating almost all crops (including oilseed crops).

Heat plays a key role in the growth and development of oilseeds, since the accumulation of the main active substances in the resulting crop depends on thermal and light energy. Due to their xeromorphic nature, they are adapted to high temperatures.

In the Southern Steppe zone of Ukraine the sum of active air temperatures (above $10^{\circ} \mathrm{C}$ ) is $3250-3400^{\circ} \mathrm{C}$ (Table 2).

According to the long-term data of the State Hydrometeorological Service of Ukraine, Hydrometeorological Centre of the Black and Azov Seas, Kherson Regional Centre for Hydrometeorology, Hydrometeorological Centre of the Autonomous Republic of Crimea, Mykolayiv and Zaporizhzhia Centres of Hydrometeorology rainfall in the northern part is $380 \ldots 440 \mathrm{~mm}$, in the middle part it is $340 \ldots 380$, and in the southern part it is $300 \ldots 340 \mathrm{~mm}$. 
Table 2: Temperature conditions of the Southern Steppe of Ukraine (annual averages)

\begin{tabular}{|c|c|c|c|c|c|c|c|c|c|c|c|}
\hline \multirow{3}{*}{$\begin{array}{c}\text { Weather } \\
\text { station location }\end{array}$} & \multicolumn{3}{|c|}{ Duration of the period, days } & \multirow{3}{*}{$\begin{array}{l}\text { The sum } \\
\text { of temp- } \\
\mathrm{s} \text { above } \\
10^{\circ} \mathrm{C}\end{array}$} & \multicolumn{7}{|c|}{ Temperature of air, ${ }^{0} \mathrm{C}$} \\
\hline & \multirow{2}{*}{$\begin{array}{l}\text { without } \\
\text { frosts }\end{array}$} & \multicolumn{2}{|c|}{$\begin{array}{c}\text { with air temperature } \\
\text { higher than }\end{array}$} & & \multirow{2}{*}{$\begin{array}{l}\text { Avg. } \\
\text { in a yea }\end{array}$} & \multirow{2}{*}{$\cdot \overbrace{0}^{\infty}$} & \multirow{2}{*}{$\begin{array}{l}\overline{\mathrm{d}} \\
\overline{\mathbf{g}} \\
\overline{\mathrm{g}}\end{array}$} & \multirow{2}{*}{ 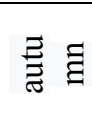 } & \multirow{2}{*}{ 竞 } & \multicolumn{2}{|c|}{ absolute } \\
\hline & & $5^{\circ} \mathrm{C}$ & $10^{\circ} \mathrm{C}$ & & & & & & & $\min$ & $\max$ \\
\hline Melitopol & 175 & 220 & 175 & 3250 & 9.4 & 9.0 & 21.7 & 10.0 & -3.3 & -33.0 & 40.0 \\
\hline Mykolaiv & 200 & 225 & 185 & 3360 & 9.6 & 9.2 & 21.6 & 10.5 & -3.3 & -33.0 & 39.0 \\
\hline Berdiansk & 185 & 220 & 175 & 3250 & 9.5 & 8.3 & 22.3 & 10.5 & -3.1 & -31.0 & 39.0 \\
\hline Odesa & 195 & 230 & 185 & 3250 & 9.4 & 8.4 & 20.8 & 10.5 & -3.3 & -33.0 & 37.0 \\
\hline Jankoy & 200 & 230 & 185 & 3350 & 10.3 & 9.1 & 22.3 & 11.3 & -3.3 & -33.0 & 38.0 \\
\hline Kherson & 180 & 230 & 185 & 3350 & 9.8 & 9.3 & 21.7 & 10.5 & -3.3 & -33.0 & 39.0 \\
\hline Skadovsk & 200 & 230 & 185 & 3400 & 99 & 88 & 217 & 112 & $-3,3$ & -330 & 380 \\
\hline
\end{tabular}

Based on the amount of rainfall, the Southern Steppe zone of Ukraine is characterized by the insufficient moisture (Table 3).

Table 3: Distribution of rainfall by seasons in the Southern Steppe of Ukraine (average annual data)

\begin{tabular}{|c|c|c|c|c|c|c|c|c|c|c|c|}
\hline \multirow{3}{*}{$\begin{array}{l}\text { Weather station } \\
\text { location }\end{array}$} & \multicolumn{10}{|c|}{ Distribution rainfall during for a year, $\mathrm{mm}$} & \multirow{3}{*}{$\begin{array}{c}\text { Average for } \\
2017-2019 \\
\mathrm{~mm}\end{array}$} \\
\hline & \multicolumn{2}{|c|}{ for a year } & \multicolumn{2}{|c|}{ winter } & \multicolumn{2}{|c|}{ spring } & \multicolumn{2}{|c|}{ summer } & \multicolumn{2}{|c|}{ autumn } & \\
\hline & $\mathrm{mm}$ & $\%$ & $\mathrm{~mm}$ & $\%$ & $\mathrm{~mm}$ & $\%$ & $\mathrm{~mm}$ & $\%$ & $\mathrm{~mm}$ & $\%$ & \\
\hline Melitopol & 426 & 100 & 123 & 28.9 & 100 & 23.5 & 117 & 27.4 & 86 & 20.2 & 398.9 \\
\hline Mykolaiv & 410 & 100 & 75 & 18.3 & 93 & 22.7 & 151 & 36.9 & 91 & 22.1 & 370.6 \\
\hline Berdiansk & 380 & 100 & 86 & 22.6 & 85 & 22.4 & 119 & 31.3 & 90 & 23.7 & 357.8 \\
\hline Odesa & 377 & 100 & 63 & 16.7 & 80 & 21.2 & 142 & 37.7 & 92 & 24.4 & 350.1 \\
\hline Jankoy & 361 & 100 & 81 & 22.4 & 81 & 22.4 & 113 & 31.4 & 86 & 23.8 & 352.4 \\
\hline Kherson & 343 & 100 & 66 & 19.2 & 82 & 23.9 & 115 & 33.5 & 80 & 21.4 & 331.7 \\
\hline Skadovsk & 307 & 100 & 60 & 19.5 & 71 & 23.1 & 92 & 30.0 & 84 & 27.4 & 301.5 \\
\hline
\end{tabular}

The maximum possible evaporation exceeds the indicated value about twice more. During the studied years, the amount of precipitation was lower than the long-term average by $10 \%$ (Table 3 ), but a long rainless period during the growing season of sunflower plants led to stress in plants, which affected their growth, development and yield. This is confirmed by the values of hydrothermal coefficient (HTC), which is $0.6-0.9$, that indicates that the area belongs to the arid zone. In such circumstances, a sharp imbalance is formed with the moisture content in the plants. That requires special technological operations and agrotechnical measures to reduce negative effects of drought.

Rainfall is distributed unevenly throughout a year. The sum of rainfall during the period with air temperature above $10^{\circ} \mathrm{C}$ equals 230 $260 \mathrm{~mm}$, that is $60-65 \%$ of the total. Little ineffective precipitation falls out from 1 to 5 $\mathrm{mm}$ for twenty-four hours often enough. Such rains fall in a period with a high temperature and low humidity of air, strong winds, and therefore they are ineffective. The probability of occurrence of rainless periods of more than 50 days is $40 \%$. Almost annually, for three to six ten-days periods or more, the plants grow under the unfavorable soil moisture, mode that is, when the productive moisture reserves in the plow layer are less than $19 \mathrm{~mm}$. Under such conditions, the amount of water coming into the plants from the soil, cannot satisfy the need for transpiration; the cells of the plants lose their turgor state, and in case of severe hot winds even die. The adverse effects of unstable moisture and periodic droughts in the summer affect the productivity of all field crops.

On the basis of the experimental data, we performed the regression analysis and constructed a linear regression model of the dependence of sunflower yield on agrometeorological indicators. The indicated model is:

$$
\hat{y}=12,6885+0,0094 x_{1}+0,1619 x_{2}-0,0031 x_{3}
$$

where $\mathrm{y}$ - the productivity, centner/ha;

$\mathrm{X}_{1}$ - the rainfall during the growing season; $\mathrm{x}_{2}-$ the minimum relative humidity of the air during flowering; 
$\mathrm{x}_{3}$ - the sum of active temperatures for the growing season.

The multiple correlation coefficient $r_{y=1 \times 2 \times s}=0,9435$ indicated a strong linear correlation between yield and rainfall ( $\left.\mathrm{x}_{1}\right)$, minimum relative humidity during flowering (x2) and the sum of active temperatures during the growing season $\left(\mathrm{x}_{3}\right)$.

The value of the determination coefficient $R_{y x_{1} x_{2} x_{3}}^{2}=0,8902$ shows that the studied factors have the high level of influence on the yield of sunflower in comparison with the action of chance. We have found that the minimum relative humidity of $54 \%$ has the highest share of influence on the sunflower yield [36].

In recent years, the minimum relative humidity during the growing season of sunflower plants has been in the range of 25 to $45 \%$, and the amount of rainfall during the growing season has been from 150 to $250 \mathrm{~mm}$. Under these conditions, the sunflower yield does not exceed 11 centner/ha [37].

Therefore, the task of plant breeders is to create high-yielding varieties and hybrids of crops that are resistant to adverse biotic and abiotic environmental factors [38]. In the last few years, even in one soil and climate location, significant fluctuations in hydrothermal values over the years can be observed, which significantly affects the realization of biological capabilities of crops, and as a result, their macrocharacteristics (including the yield). This is precisely what the requirements for the adaptive potential of the cultivated varieties and hybrids of field crops are. The evaluation of plant breeding material for adaptability and stability is the basis for the selection of highly adaptive sunflower forms.

A mandatory feature of any organism is the ability to protect against the effects of adverse abiotic and biotic environmental factors. This function had appeared simultaneously with the emergence of the first living organisms and developed and improved in the course of further evolution. The adaptation of an organism to specific conditions of existence is achieved in the individual at the expense of physiological mechanisms (physiological adaptation), and in a population of organisms (species) it occurs due to mechanisms of genetic variability and heredity (genetic adaptation).

The intensification of crop production should be based on the use of the adaptive potential of agrophytocenosis, a comprehensive approach to improving its adaptability, the use of selection, exogenous regulation of adaptive reactions, optimization of environmental conditions and creation of highly productive and environmentally sustainable agrophytocenoses. Our research on the determination of more adapted varieties and hybrids to biotic and abiotic factors on crop yields began in 2013 [36, 39].

Briggs F. and Knowles P. [40] proposed to call a variety stable if it is resistant to a wide range of environmental factors, as to cultivated plants. Varieties with high potential productivity are more likely to "scan" the uneven distribution of abiotic and biotic environmental factors. However, increasing the potential productivity of varieties and agrophytocenoses is not the only way to intensify crop production. Only a steady increase in the average crop yield over many years can be a reliable criterion of the efficiency.

At the present stage of science development, mathematical modeling methods, especially such as the cluster analysis, stability and plasticity studies by S.A. Eberhart and W.A. Russel, play an increasing role in the adequate evaluation of sunflower varieties and hybrids.

The ecological plasticity of a variety or hybrid is called its biological ability to adapt to changing environmental conditions. Adaptability of the variety (hybrid) should also be considered from the standpoint of stability.

The stability and plasticity of hybrids by yield were determined by the methods of S.A. Eberhart and W.A. Russel. In this case, the criterion of "weather conditions of the year" was used as the criterion of "item". In this modification, we determined the stability and plasticity of the hybrids for the meteorological conditions of the research experimental plot.

According to the method of S.A. Eberhart and W.A. Russel, the comparison of hybrids 
within the sample of the presented hybrids was performed by the coefficient of regression $b_{i}$ or the coefficient of plasticity.

According to the Eberhart and Russel model, the most valuable and high-intensity hybrids are $b i>1$. These hybrids respond well to improved growing conditions and are characterized by stable yields. The high index of bi varieties are less valuable because their high sensitivity is accompanied by low stability of yield. Genotypes with bi<1 are low sensitive to the improvements in their environmental conditions (half sensitive), but demonstrate rather high yield stability (Russel, 1966). That is, genotypes with a value bi close to one are considered the most suitable for cultivation in this region, because the change in their yield is fully consistent with fluctuations under growing conditions. If bi is much higher than one, then these varieties belong to the intense and they respond well to improved growing conditions, but in adverse of to the weather conditions of the year reduce the productivity sharply. When bi is much less than one, then such varieties are suitable only for growing by extensive cultivation technology.

For our research, we chose the method of S.A. Eberhart and W.A. Russell. This method allows us to reveal the relationship between plant productivity and agrometeorological conditions of a certain region, which is very relevant under the conditions of climate changes.

During 2017-2019, the ecologically plasticity and stability of sunflower hybrids were determined (Table 4).

To determine the stability, we first defined the average yield for each hybrid according to the following formula (4):

$$
Y i=\overline{x i}+\text { Bi } \mathrm{Ij}
$$

$\overline{\mathrm{xi}}$ - the average yield of a particular hybrid for all years of research, $t /$ ha ;

вi $\mathrm{Ij}$ - the product of the regression coefficient of a particular hybrid by the index of environmental conditions.

The range of yield changes varied across hybrids and years of the study from 1.68 to $2.51 \mathrm{t} / \mathrm{ha}$, and the average yield over the years in terms of hybrids was $1.99 \mathrm{t} / \mathrm{ha}$.
We calculated a regression coefficient bi for each hybrid:

$$
\text { bi }=\frac{\sum v / \% \text { Ij }}{\Sigma j^{2}}
$$

$\sum$ Yij - the sum of yield of a particular hybrid in a particular year;

$\mathrm{Ij}$ - - the index of environmental conditions;

$\sum \mathrm{Ij}^{2}$ - the sum of squares for the indices of environmental conditions.

At the same time, certain genotypes have an average group value of plasticity of the yield characteristic sign property (ranging from 0.83 to 1.19), namely: EU Arcadia SU, EU Genesis, NS-X-496, EU Generalis SL, EU Loris KLP, SI Bacardi KLP and SI Arizona. The yield of these hybrids varies depending on growing conditions.

Low environmental plasticity was found in hybrids: LG 5555 CLP, LG 5542 and NK Neoma. These hybrids are best grown on an extensive background, as they are able to form the maximum yield at minimum investments.

Those hybrids in which the ecological plasticity was greater than 1 are characterized as adaptive and intensive (increasing productivity directly depends on improving the conditions of cultivation technologies).

The analysis of the sign of stability was of interest to us in terms of determining the average group constant, since the sign of stability is more conditional than the indicator of plasticity.

Homeostatic (stable) variety is one that has a coefficient below one. Homeostasis is a universal means of self-regulation in the system of the body relationship with the external environment, is the ability of the genotype to minimize the effects of adverse conditions [41].

To determine the stability of the yield of sunflower hybrids, we calculated the deviation of the actual yield from the potential one by the following formula:

$$
\sigma \mathrm{ij}=\mathrm{Yij}-\widehat{\mathrm{Y}} \mathrm{i}
$$

Yij - the actual yield of a particular hybrid in a particular year, $\mathrm{t} / \mathrm{ha}$;

Yij - the potential yield of a particular hybrid in a particular year, $t /$ ha. 
Table 4: Productivity of sunflower hybrids, t/ha (2017 - 2019)

\begin{tabular}{|l|c|c|c|c|c|c|}
\hline \multirow{2}{*}{ Hybrid } & \multicolumn{3}{|c|}{ Year } & $\begin{array}{c}\text { Average yield of } \\
\text { hybrids }(Y \mathrm{Y})\end{array}$ & $\begin{array}{c}\text { Linear regression } \\
\text { component }\left(\mathrm{b}_{\mathrm{i}}\right)\end{array}$ & $\begin{array}{c}\text { Stability } \\
\left(\mathrm{\sigma d}^{2}\right)\end{array}$ \\
\cline { 2 - 4 } & 2017 & 2018 & 2019 & 1.68 & 0.92 & 0.35 \\
\hline ES Arcadia SU & 2.05 & 1.47 & 1.52 & 1.74 & 0.98 & 0.41 \\
\hline ES Henezis & 2.13 & 1.69 & 1.39 & 2.05 & 2.10 & 0.52 \\
\hline SY Cadix & 2.89 & 1.84 & 1.42 & 2.22 & 1.13 & 0.67 \\
\hline ES Generalis CL & 2.67 & 2.00 & 1.98 & 1.86 & 0.53 & 0.36 \\
\hline LG 5463 CL & 2.07 & 1.95 & 1.55 & 1.89 & 0.79 & 0.44 \\
\hline Rimisol & 2.21 & 1.68 & 1.79 & 2.11 & 1.41 & 0.57 \\
\hline ES Janis & 2.67 & 2.16 & 1.49 & 2.51 & 1.19 & 0.82 \\
\hline ES Loris CLP & 2.99 & 2.48 & 2.07 & 1.70 & 0.56 & 0.29 \\
\hline NS-X-498 & 1.92 & 1.63 & 1.54 & 1.70 & 0.92 & 0.41 \\
\hline NS-X-496 & 2.10 & 1.84 & 1.26 & 1.73 & 0.16 & 0.58 \\
\hline LG 5555 CLP & 2.02 & 1.80 & 2.43 & 2.08 & 0.35 & 0.52 \\
\hline LG 5542 & 2.09 & 2.00 & 2.58 & 2.22 & 1.83 & 0.42 \\
\hline P64LE25 & 2.54 & 1.47 & 1.41 & 1.81 & 0.54 & 0.51 \\
\hline LG 5543 CL & 1.94 & 2.05 & 2.48 & 2.16 & 1.55 & 0.56 \\
\hline LG 59580 & 2.78 & 1.31 & 2.39 & 2.16 & 1.18 & 0.57 \\
\hline Bakkardi & 2.64 & 2.12 & 1.75 & 2.17 & 1.88 & 0.32 \\
\hline Sumico & 2.75 & 1.46 & 1.78 & 1.99 & 0.83 & 0.52 \\
\hline SY Arisona & 2.70 & 2.35 & 2.05 & 2.37 & 0.61 & 0.92 \\
\hline Primi & 2.21 & 1.94 & 1.76 & 1.97 & 0.52 & 0.19 \\
\hline Estrada & 1.94 & 1.75 & 1.53 & 1.74 & 1.37 & 0.41 \\
\hline Subaro & 2.57 & 1.56 & 1.93 & 2.02 & 1.42 & 0.18 \\
\hline P64HE118 & 2.38 & 1.85 & 1.21 & 1.81 & 0.36 & 0.19 \\
\hline NK Neoma & 2.01 & 1.95 & 1.64 & 1.87 & &
\end{tabular}

The mean-square deviation (stability) was calculated by the formula:

$$
\sigma \mathrm{d}^{2}=\frac{5 \mathrm{gij} 2}{n-2}
$$

$\sum \sigma i j^{2}$ - the sum of squares of deviation of the actual from potential yields;

$\mathrm{n}$ - the number of years.

According to the calculations in Table 4, the stability varies from 0.18 in the P64HE118 hybrid to 0.92 in the Primi hybrid. A smaller value of $\sigma \mathrm{d}^{2}$ indicates a smaller deviation of the actual yield from the potential one during all the years of research, which confirms the stability of this hybrid. A low stability index indicates a high degree of response to changes in environmental conditions. There is no significant difference between the hybrids in this indicator.

Of particular value are plastic varieties or hybrids that have the medium or high yield, a regression coefficient is equal to 1 or greater than 1, and a stability close to 0 . This combination of indexes indicates that the productivity of this genotype responds to changes in the environment. The hybrid P64HE118 can be attributed to this genotype.

\section{Conclusion}

Determination of stability and plasticity coefficients allows to reveal productivity stable sunflower hybrids, with a high level of plasticity and to recommend them for production in certain cultivation regions of Ukraine. Adaptive cultivation technologies stipulate the increase of stability of sunflower hybrid productivity of different selection.

We used the Eberhard and Russel method (the plasticity and stability analysis) to fully evaluate new hybrids with regard to their adaptability to growing conditions and investigate the appropriate rate of response of genotypes to the growing technology.

The hydrothermal coefficient in 2017 was 0.75 . Despite this, the sunflower plants formed the highest yield that year due to the sufficient minimum relative humidity of the air during flowering (BBCH 61-65) [42] was 54.7\%.

The range of yield changes across hybrids and years of study ranged from 1.68 to 2.51 $\mathrm{t} / \mathrm{ha}$, and the average over the years in terms of hybrids yielded $1.99 \mathrm{t} / \mathrm{ha}$. 
According to the plasticity coefficient, a group of hybrids is selected, which respond positively to the optimal weather conditions of cultivation by significantly increasing the yield. This group includes: SY Cadix, P64LE25, Sumico, ES Janis, LG 59580, Subaro and P64HE118.

The stability varies from 0.18 in the P64HE118 hybrid to 0.92 in the Primi hybrid.

The P64HE118 hybrid was one of the entire list of studied hybrids of sunflower that showed little response to various agricultural meteorological conditions during the growing season. All other hybrids indicated moderate

\section{References:}

[1] Gomes, D.P.; et al. Qualidade fisiológica e sanitária de sementes de girassol cultivadas em Timon, MA. Summa Phytopathologica, Vol. 32, 2006, pp. 291/3-292.

[2] Yeremenko, O.A.; Kalytka, V.V.; Kalenska, S.M.; Malkina, V.M. Assessment of ecological plasticity and stability of sunflower hybrids (Helianthus annuus L.) in Ukrainian Steppe. Ukrainian Journal of Ecology, Vol. 8, No. 1, 2018, pp. 289-296 doi: 10.15421/2018_214.

[3] Mohamed, M.Y. Development and stability of some Sudanese sunflower hybrids under irrigated conditions, Helia, Vol. 33, No. 52, 2010, pp.135-144.

[4] Starichenko, V.M.; Golik, L.M.; Tkachev, N.A. Evaluation of adaptive capacity and stability of varieties and breeding lines in the winter wheat. Plant Breeding and Seed Production, Vol. 105, 2014, pp.77-84.

[5] Ali, S.S.; Manzoor, Z.; Awan, T.H.; Mehdi, S.S. Evaluation of performance and stability of sunflower genotypes against salinity stress. The Journal of Animal and Plant Science, Vol. 16, No. 1-2, 2006, pp.47-51.

[6] Kyrychenko, V.V.; Tsehmeistruk, M.G.; Riabchun, N.I.; Ogurtsov, Yu.E. State and prospects of the development of agriculture in Kharkiv region in terms of climate change. Bulletin of the Centre for Science Provision of Agribusiness in Kharkiv region, Vol.10, 2011, pp.10-26.

[7] Byelyenihina, A.V.; Kostromitin, V.M. Cultivars of millet seeds by agro-ecological resistance. We found that the performance of the studied hybrids was independent of their genetic properties. Environmental conditions had the greatest impact on this indicator.

The authors continue research on other crops in this field under the conditions of southern steppes of Ukraine. The obtained results will allow not only to recommend more plastic varieties and hybrids to agricultural producers, but will also provide an opportunity to develop a mathematical model for calculating the adaptive capacity of plants for certain climatic growing conditions.

stability and plasticity. Variety Studying and Variety Science, Vol. 106, 2014, pp.141147.

[8] Korzun, A.S.; Bruylo, A.S. Adaptive features of selection and seed farming of agricultural plants. Grodno: HHAU, 2011, $140 \mathrm{p}$.

[9] State register of plant varieties suitable for dissemination in Ukraine in 2019: www.http://vet.gov.ua/node/919

[10] Hatfield, J.; Boote, K.; Kimball, B.A.; et al. Climate Impacts on Agriculture: Implications for Crop Production. Agronomy Journal. Vol. 103, 2011, pp. 351-370.

[11] Dragavtsev, V.A. About the ways of creating the theorem of selection and technologies of ecogenetic increase in productivity and plant yield. Factors the experimental evolution of organisms. K., Logos, Vol. 13, 2013, pp. 38-41.

[12] Ali, S.; Uddin, S.; Ullah, O.; et al. Yield and Yield components of Maize Response Tocompost and Fertilizer-Nitrogen. Food Science and Quality Management. Vol. 38, 2015, pp. 39-44.

[13] Melnyk, A.V. Agrobiological features of sunflower and rape growing under the conditions of the North-Eastern Forest-Steppe zone of Ukraine. Sumy: Universytetska knyha. 2007, 229 p.

[14] Schmalhausen, I.I. Factors of Evolution. The Theory of Stabilizing Selection. Blakiston: Philadelphia, 1949, 326p.

[15] Waddington, C.H. Canalization of development and the inheritance of acquired characters. Nature, Vol. 150, 1942, pp. 563-565. 
[16] Flatt, T. The evolutionary genetics of canalization. $Q$ Rev Biol, Vol. 80, 2005, pp.287-316.

[17] Dimitrov, S.G. The stability and flexibility of modern sunflower hybrids. Scientific Magazine NSC "Institute of Agriculture NAAS", Vol. 3, 2015, pp.117-124.

[18] Eberhart, S.A.; Rassel, W.A. Stability parameters for comparing varieties. Crop Sci, Vol. 6, 1966, pp.36-40.

[19] Tai, G.C.C. Genotypic stability analysis and its application to potato regional trials. Crop. Sci, Vol.11, No. 2, 1971, pp.184-190.

[20] Mamontova, V.N. Selection and seedgrowing of spring wheat. Publishing house "Kolos", Moscow, Russia, 1980, 286p.

[21] Pakudin, V.Z.; Lopatina, L.M. Assessment of ecological plasticity and stability of varieties of agricultural crops. Agricultural Biology, Vol. 4, 1984, pp.109-113.

[22] Moskalets, T.Z. Stability and plasticity of wheat soft winter genotypes in the foreststeppe ecotope. Bulletin of the society geneticists and seed scientists Vavilov in Ukraine, 2015, Vol. 13, №1, pp. 51-55.

[23] Levchenko T., Baydyuk T. Environmental ductility and stability of collection samples of white lupine. Scientific magazine NSC "Institute of agriculture NAAS", Vol. 3-4, 2016, pp. 187-196.

[24] Sadras, V.O.; Rebetzke, G.J. Plasticity of wheat grain yield is associated with plasticity of ear number. Crop and Pasture Science 64(3), 2013, pp. 234-243 https://doi.org/10.1071/CP13117

[25] Grogana, S.M.; Andersonc, J.; Baenziger, P.S.; et al. Phenotypic Plasticity of Winter Wheat Heading Date and Grain Yield across the US Great Plains. Crop Science. Vol. 56(5), 2016, pp. 2223-2236.

[26] Vasyliuk, P.M. Estimation of stability and plasticity indices of productivity and quality of new varieties of bread winter wheat in the conditions of Forest-Steppe of Ukraine. Sortovyvchennia ta Okhorona Prav na Sorty Roslyn, Vol. 1, 2014, pp.15-18.

[27] Soil quality. Fertility indexes of soils: DSTU 4362:2004 [Valid from 2006-01-01], Derzhspozhivstandart of Ukraine, 25p., 2006 (National standard of Ukraine).

[28] Soil quality. Sampling Part 1. Guidance on the design of sampling programmes: DSTU
ISO 10381-1:2004 [Valid from 2006-04-01], Derzhspozhivstandart of Ukraine, 62p., 2006 (National standard of Ukraine).

[29] Soil quality. Methods of determination of organic matter: DSTU 4289:2004 [Valid from 2005-07-01], Derzhspozhivstandart of Ukraine, 12p., 2005 (National standard of Ukraine).

[30] Gerkial, O.M; Gospodarenko, G.M; Kolarkov, Y.V. Agrochemistry: Study Guide. Uman. 2008, 300p.

[31] Soil quality. Determination of mobile compounds of phosphorus and potassium using modified Chirikov method: DSTU 4115-2002. [Valid from 2002-07-18], Derzhspozhivstandart of Ukraine, 13p., 2002. (National standard of Ukraine).

[32] Brown, D.M; Bootsma, A. Crop heat units for corn and other warm season crops in Ontario. Factsheet Ministry of Agriculture, Food and Rural Affairs. Ontario. 1993, pp. $32-41$.

[33] Tsupenko, N.F. Reference book by the agronomist on agricultural meteorology. Ukrainian: Harvest, 1990, 238p.

[34] Yashchuk, V.U.; Vashcenko, V.M.; Krivosheya, R.M.; Tsybulnyak, Y.O.; Koretsky, A.P. List of pesticides and agrochemicals permitted for use in Ukraine. Publishing house "Univest Media", Kyiv, Ukraine, 2016, 1024p.

[35] Rozhkov, A.O.; Puzik, V.K.; Kalensjka, S.M.; Puzik, L.M.; Popov, S.I.; Muzafarov, N.M.; Bukhalo, V.Ja.; Kryshtop, Je.A. Doslidna sprava $v$ aghronomiji [Pilot case in agronomy], Kharkiv: Majdan, No. 1, 2016, 316p.

[36] Yeremenko, O.A. Agrobiological fundamentals of oilseeds (Helianthus annuus L., Carthamus tinctorius L., Linum usitatissimum L.) production in the Southern Steppe of Ukraine. Qualifying scientific work on the rights of the manuscript. 2018, $485 \mathrm{p}$.

[37] State Statistics Service of Ukraine: http://www.ukrstat.gov.ua.

[38] Cattivelli, L.; Rizza, F.; Badeck, F.W.; et al. Drought tolerance improvement in crop plants: an integrated view from breeding to genomics. Field Crops Res. Vol. 105, No. $1-2, \quad 2008$, pp. 1-14. doi: $10.1016 /$ j.fcr.2007.07.004 
[39] Kalenska, S.M.; Yeremenko, O.A.; Taran, V.H.; Krestianinov, Ye.V.; Ryzhenko, A.S. Adaptability of field crops to changing conditions of cultivation. Scientific Papers of the Institute of Bioenergy Crops and Sugar Beet, Vol. 25, 2017, pp. 48-57.

[40] Briggs, F.N.; Knowles, P.F. Introduction to Plant Breeding. Reinhold Publishing Corp. New York. 1967, 383p.

[41] Hangildin, V.V. About modeling principles varieties of intensive type. Genetika kolichestvennyh priznakov sel'skohozyajstvennyh rastenij, 1978, pp. 111-116.

[42] Biologische Bundesanstalt fur land und Forstwirtschaft Entwicklungsstadien mono und dikotyler Pflanzen. BBCH-Monograph. Blackwell Wissenschafts - Verlag Berlin Wien. 1997, 622p. 